\section{Cerebrovascular Diseases}

\section{Laudatio}

Cerebrovasc Dis 2006;22:340-341

DOI: $10.1159 / 000094848$
Published online: August 3, 2006

\title{
Johann Jacob Wepfer Award 2006 of the ESC to Prof. Markku Kaste
}

Prof. Markku Kaste is the 2006 winner of the J.J. Wepfer Award for his major contributions in research and education in cerebrovascular diseases and organisation of stroke care.

Prof. Markku Kaste was born in Helsinki in 1941, where he did most of his education, medical and neurological training. He obtained his MD degree in 1970. From 1981 to 1982 he was Visiting Professor at the University of Missouri, USA. In 1993 he was appointed Associate Professor and in 2001 he became Chair Professor of Neurology at the University of Helsinki. He is also Chairman of the Department of Neurology of Helsinki University Central Hospital.

Prof. Markku Kaste has produced an extensive bibliography of more than 200 scientific publications, mainly in different topics of stroke and related disorders.

Prof. Markku Kaste has served in several scientific associations and organizations, including the Scandinavian Society for the Study of Cerebrovascular Diseases, WHO, EMEA, EFNS, EUSI, ESC, WSF, ISS and also in the journals Stroke, Cerebrovascular Diseases and International Stroke Journal. He has to be congratulated in particular on his position as European editor of Stroke and member of the International Stroke Liaison Committee of the AHA.
Prof. Markku Kaste had a leading role in several multicentre trials of secondary stroke prevention and acute stroke treatment with neuroprotection and thrombolysis, in particular ECASS I and II. He promoted the active participation of Finland and Scandinavia in many such trials. He was Chairman of EUSI and founding member of the EUSI Virtual Stroke University and of the EUSI European Master Stroke Program. He took particular interest and engagement in the education of young physicians, supporting stroke education by regular summer schools of EUSI and in the distribution of evidence-based medicine in stroke through EUSI recommendations for stroke treatment and diagnosis during his Presidency of EUSI.

With these and other activities Markku Kaste has made a significant contribution to the progress of stroke research, care and education in Europe.

His kindness and calm and good-humoured personality are other characteristics of his that make him unique among the European stroke community.

José M. Ferro

\begin{tabular}{ll}
\hline KARGER & ( ) 2006 S. Karger AG, Basel \\
1015-9770/06/0226-0340\$23.50/0 \\
$\begin{array}{l}\text { Fax +4161306 12 34 } \\
\begin{array}{l}\text { E-Mail karger@karger.ch } \\
\text { www.karger.com }\end{array}\end{array}$ & $\begin{array}{l}\text { Accessible online at: } \\
\text { www.karger.com/ced }\end{array}$
\end{tabular}




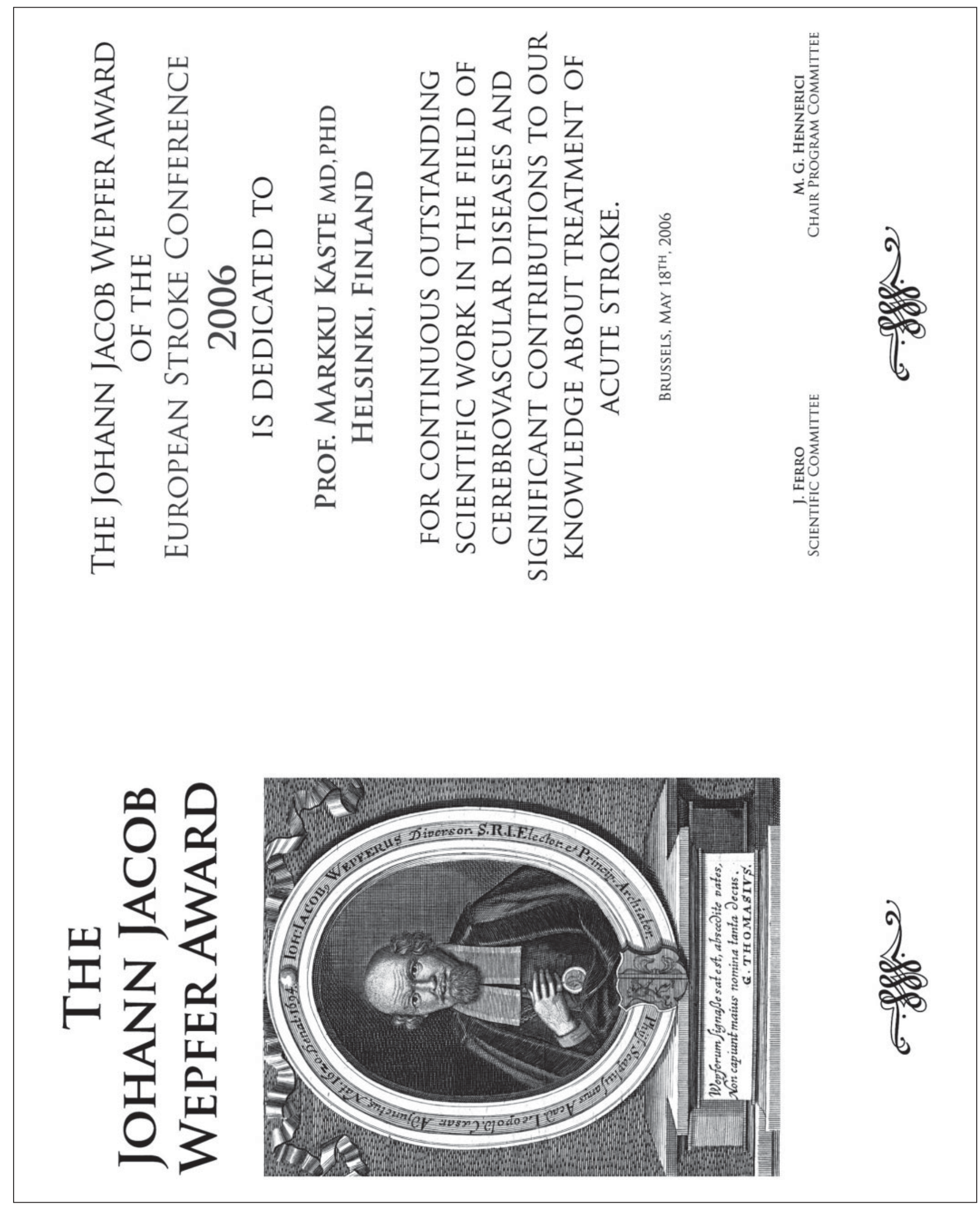

